\title{
Media Control: A Case for Privatization in Transitional Economies
}

\section{Fran Galetić, Marina Dabić \& Timothy Kiessling}

To cite this article: Fran Galetić, Marina Dabić \& Timothy Kiessling (2016) Media Control: A Case for Privatization in Transitional Economies, Journal of Media Economics, 29:3, 111-124, DOI: 10.1080/08997764.2016.1206907

To link to this article: https://doi.org/10.1080/08997764.2016.1206907

曲 Published online: 25 Aug 2016.

Submit your article to this journal $\pi$

Ull Article views: 255

Q View related articles $₫$

View Crossmark data $\nearrow$

Citing articles: 2 View citing articles $\sqsubset$ 


\title{
Media Control: A Case for Privatization in Transitional Economies
}

\author{
Fran Galetića, Marina Dabić (10), and Timothy Kiessling ${ }^{b}$ \\ ${ }^{\mathrm{a}}$ Faculty of Economics and Business, University of Zagreb, Zagreb, Croatia; ${ }^{\mathrm{b}}$ Faculty of Business Administration, \\ Bilkent University, Ankara, Turkey
}

\begin{abstract}
The television market can be one of the most dynamic industries if country-specific regulations allow for private competitors to enter the market. The entry of competition changes the market from monopolistic to oligopolistic, which has positive performance implications for the industry. Our research analyzes the development of the Croatian TV market from the monopolistic stage to the current oligopolistic stage. Econometric models in this article aim to estimate the current trend of market concentration and its future potential. The authors' research focusing on the industry from a market concentration perspective provides guidance for the practitioner in regard to profitable investment opportunities. They also illustrate for other transitional economies that to move toward a "free" society, media must be free from government control which will evolve rapidly once privatized.
\end{abstract}

Similar to other television markets in the world, the Croatian TV market developed from a monopolistic market where the state-owned television was the one and only broadcaster for TV programs (Zampetakis, Vekini, \& Moustakis, 2014). In the 1980s, European TV markets started the process of liberalization in which many new private TV channels emerged. Since then, the role of public broadcasting channels has been reduced, a large number of private channels have been introduced, and the concentration of channel ownership has first declined and then increased (Dahlgren, 2000; Iosifides, 1999). The process of liberalization of the television market in Croatia started in 1989, when the first commercial TV station, OTV, started to broadcast to a small local market. The real effects of liberalization on the national level occurred 11 years later when the first private TV station with a national concession started broadcasting.

The majority of the revenue for the TV market comes from advertising. As such, the main motive for entering any TV market is always based on the possible profit that could be made from advertising. TV channels with the largest share of the market can sell advertising time for the highest amount of money. An analysis of the market is important to determine who the key players in the market are, as they will command the largest share of the industry revenue. The importance of our research is illustrated by the amount of spending on television advertising. Television advertising reached $\$ 186$ billion in 2013 and is expected to grow at an annual rate of over 6\% per year globally. Some examples of the magnitude is spending in the United States averages about $\$ 48$ billion and in Germany 4 billion euros (McKinsey, 2013). Croatia is the youngest member of the European Union (EU), but it has historically always been part of Europe, and accordingly the Croatian TV market is similar to the evolution of the EU TV markets. This means that this analysis can also be applied to other countries. 
Our research first investigates the process of the development of the TV market at the national level using the Croatian market. The analysis includes TV channels that broadcast with a nationwide concession covering the majority of the population. The basis for the analysis is the market share for each TV channel at the national level, which is recalculated from the market shares obtained by using the SHR method in the way that all nationwide channels form one unique TV market. Values obtained in this way serve to calculate the certain measures of concentration, which will show the level of market concentration. This is very important for further development of the market, especially for possible new entries into the market. But the level of concentration is also the key factor for mergers and acquisitions (M\&A) on the market, because the competition agency will not allow the rise of concentration above some higher level based on M\&A. According to the analysis for 2008, Croatia has, together with countries like Italy and Finland (Hirschman-Herfindahl index $[\mathrm{HHI}]>1,800)$, high concentration on the television market, whereas on the other side are countries like Turkey and Romania $(\mathrm{HHI}<1,000)$ with low concentration on the television market (Berg, 2010).

We then provide direction for practitioners through trend analysis for each of the national TV channels and calculate the predicted values of market share for the next three years. The values obtained in this way will serve as the basis for calculating the future predicted values of measures of concentration. This will show the direction of the Croatian TV market at the national level for the next few years. The level of concentration has been falling with the entry of new channels on the market. But at the same time there were changes in the leading channel. Because of the constant growth of the market share of the current leading TV channel, it is expected that after years of falling, the level of concentration will start to grow again.

Finally, our research contributes in a societal level. For a society to be "free" the media must be free from government control. When the Croatian television market was privatized, newcomers quickly took market share from the government firms. As of 2015, the government controlled television channels are no longer dominant in respect to the number of viewers. Even more importantly were the global/foreign firms that entered the Croatian market, as the top firm is foreign. These firms offer a global perspective and are not influenced by the government and offer programming that will deliver an eclectic view. Transitional governments that are seeking transparency in reporting, unbiased (to an extent that exists) reporting, and programs chosen only for their success measured by the number of viewers, should take note of the privatization outcomes illustrated in our research.

\section{Literature review}

There are very few scientific papers that analyze the television market from an industry unit of analysis, in particular from the methodological approach using market concentration (Van Der Wurff, 2005; Johannes, 2010; Berg, 2010). There is research that analyzes market concentration in other markets, research that focuses on television markets, but not in regard to both television market and market concentration (Vázquez-Maguirrea \& Hartmann, 2013; Schmid \& Ulrich, 2013; George, 2007; Chong-En, Jie, \& Qiong, 2014).

There is relatively little research utilizing concentration measures on the television market. Past research suggests that when the Taiwan cable television industry was privatized, concentration rates went from $39 \%$ to $74 \%$ within 6 years (Chen, 2002). Other research investigated how competition, concentration and public broadcasters influence diversity of program supply in the European television markets. This research focused on Finland, France, Germany, Greece, Italy, the Netherlands, Spain, and the United Kingdom for the late 1980s and 1990s and found that competition and concentration contribute to a diverse supply of programs that mirrors audience demand (Van Der Wurff, 2005). Research that reviewed the changes in the market concentration of the cable television industry in the United States from 1996 to 2008 found that the industry had become a highly concentrated oligopoly (Johannes, 2010). 
The Mexican television market was a monopoly until 1993 when satellite TV firm Azteca Satellite entered and quickly got 30\% of the market share (Gutiérrez Rentería, 2007). The duopoly was maintained due to first mover advantages and barriers to entry (Vázquez-Maguirrea \& Hartmann, 2013). Substitute products for television (such as the internet) have been explored as entry barriers have been lowered. In Germany above average profits are indicated through internet entry challenging the oligopolistic market (Löbbecke \& Falkenberg, 2002). Other research suggested the market size had no correlation with market concentration (Berg, 2010).

The use of market concentration analysis has been used in other industries besides that of the television market. For example, Schmid and Ulrich (2013) analyzed the German hospital market. The findings indicated that shortly after hospital competition intensified, more than one third of German hospitals are now located in highly concentrated markets. Chong-En et al. (2014) used nonlinear estimation to simulate the Zipf distribution and construct an alternative measure of HHI to reveal the real changes in the monopoly of China's industrial markets. Between 1998 and 2009, China actually experienced much less competition improvement, or monopoly reduction, in many industries during this period. George (2007) examined the effect of ownership concentration on product position, product variety, and circulation in the United States daily newspaper market. Using data from 706 newspapers in 1993, 1999, and 2004, results have shown that both differentiation and variety increase with ownership concentration.

Various other television research suggests that culture seems to both attract and resist economic analysis (Doyle, 2010). Drawing on an analysis of recent research findings related to multi-platform strategies in the television industry, the author examines what is distinctive about the economics of culture, and it assesses the appeal but also the challenges associated with conducting scholarly research work in this particular area. O'Hagan and Jennings (2003) focused on key issues arising in the current debate in Europe over public sector broadcasting (PSB). The research summarizes the PSB research and then critically examines each of the arguments.

Our research attempts to fill the gap in the literature regarding TV markets of the last $13 \mathrm{EU}$ members and new EU candidates. We analyze the Croatian TV market from a market concentration perspective so that it can be evaluated and then be generalizable. We anticipate that similar research with other markets could provide further support for our results.

\section{The development of Croatian TV market at the national level}

Media ownership controlled by too few companies within a country contradicts the basic tenet of democracy as it threatens the diversity of expression and risks autocratic control of communicative spaces (Barnett, 2010). For television, as one of the media available with the strongest influence, it is especially important to have a variety of programmes reflecting a variety of opinions. Hence, the liberalization of a TV market is a very important step in each country that is moving to a democratically controlled government.

The Croatian TV market was monopolistic until the year 2000. This situation is comparable to Mexico when the only firm was Televisa. But the main difference is that Televisa is a private company, and the Croatian monopolist was government controlled. The state owned television HRT (Croatian radio-television) had three programmes, HRT 1, HRT 2, and HRT 3. The first private TV station with the national coverage, Nova TV, was launched in November 2000. It is the channel launched by the Central European Media Enterprises (CME). In 2004, the Croatian government decided to privatize the frequency on which HRT 3 was broadcasted. The best bidder for taking this frequency in a 10-year concession was the German RTL Group, which launched the new TV station in April 2004.

After the process of digitalization in Croatia was finished, several new TV stations with nationwide coverage started transmitting: RTL 2 (owned by RTL), Doma TV (owned by CME), SPTV (Sport television) and CMC (Croatian Music Channel). At the end of 2012, HRT launched two new channels, HRT 3 and HRT 4 . The first of them is a cultural channel; the second is a news channel. In 2014 RTL launched a new channel for children and family named RTL Kockica. 
Table 1. Croatian TV channels with nationwide coverage.

\begin{tabular}{|c|c|c|c|c|}
\hline Channel & Owner & Programming & Year of launch & MUX \\
\hline HRT 1 & Croatian radio-television & General & 1956 & $A$ \\
\hline HRT 2 & Croatian radio-television & General & 1972 & A \\
\hline RTL & RTL Group & General & 2004 & A \\
\hline Nova TV & CME & General & 2000 & A \\
\hline HRT 3 & Croatian radio-television & Cultural & 2012 & B \\
\hline HRT 4 & Croatian radio-television & News & 2012 & B \\
\hline RTL 2 & RTL Group & Entertainment & 2011 & B \\
\hline Doma TV & CME & Entertainment & 2011 & B \\
\hline SPTV & Croatian Olimpic Committee & Sport & 2011 & D \\
\hline CMC & Autor & Music & 2011 & D \\
\hline RTL kockica & RTL Group & Children and family & 2014 & D \\
\hline
\end{tabular}

The whole process of the development of the TV market in Croatia is similar to other countries. In Germany the liberalization of TV market started in 1984 with two private channels, RTL and SAT1. Today, the German TV market is one of the most developed markets in the world with a large number of TV stations on the national level with low levels of concentration. Similarly, Italy, where the monopoly of RAI ended in 1980 with the private channel Canale 5, there are now numerous TV channels. Based on such examples, the Croatian TV market can expect further development with the entrance of new channels on the market.

At the writing of this paper, the Croatian national TV market has 11 TV channels, which are shown in Table 1.

As shown in the Table 1, there are four general TV channels which are broadcasted in the first multiplex, Mux A. Four channels are broadcasted in Mux B, and three specialized channels are broadcasted in Mux D. Mux A has the coverage of 98\% of the population, Mux B 95\% and Mux D 90\% (OIV Ltd., n.d.). As all three multiplexes which broadcast TV channels on the national level cover the vast majority of the population, all 11 national TV channels can be analyzed equally on the national TV market.

\section{Methodology}

Our data has been taken from the Electronic Media Agency (2012). The analysis uses TV channels that broadcast with a nationwide concession. These channels cover the vast majority of the population of Croatia. The most important variable for the analysis is the market share for each channel at the national level. The market shares used in this article had been recalculated based on the SHR method so that all nationwide channels form one unique TV market. This means that all market shares obtained by the SHR method (share of all viewers in the period 0-24) have been supposed to be equal to $100 \%$, and then the market share for each TV channel has been calculated. For example, if there were just two national channels, one with $30 \%$ SHR and the other with $20 \%$ SHR (other $50 \%$ are local stations and specialized satellite and cable channels), then the market shares are $60 \%$ and $40 \%$. Values obtained in this way serve to calculate the certain measures of concentration, whose aim is to show the level of market concentration on TV market in Croatia. Market concentration is considered as the best numerical variable for measuring the market power of participants in the market (Bagdikian, 2004; Baker, 2007; Ward, 2004). Higher concentration means that there are one or fewer TV channels with high market shares. In other words, this means that such TV channels are more attractive for showing commercials, which results in higher revenue.

After all market shares have been calculated, the next part of the analysis is the development of the regression model for trend analysis. The principal idea of this analysis is to estimate the trend model for each of national TV channels in Croatia and to calculate the predicted values of market share for next three years.

For each set of data (each of $11 \mathrm{TV}$ channels' market share), we have done various econometric models. These are: 
(1) Linear trend: $y_{t}=a+b \cdot x_{t}$

(2) Exponential trend: $y_{t}=a \cdot e^{b x_{t}}$

(3) Logarithmic trend: $y_{t}=a+b\left(x_{t}\right)$

(4) Power trend: $y_{t}=a \cdot x_{t}{ }^{b}$

Based on the results of these models, we have estimated the model that best fits for each of the TV channels' trend. The criteria for the selection were coefficients of model quality. We tried a number of different specifications based upon past research and then chose the one with the highest R-squared. As there are 11 years of observations, and because of the fact that we have analyzed different theoretical models, the R-squared values are high. The models obtained in this way have served as the basis for calculating the future predicted values for measures of concentration. This analysis will show in which direction the Croatian TV market at the national level will go in next 3 years, and how the market concentration should change according to the developed trend. The major limitation of this analysis is statistical significance. As the number of observations is not large, our estimates are not statistically significant, but still can serve as a good indicator of changes on television market in Croatia.

Market concentration in this article has been calculated using different measures of concentration (concentration ratio, $\mathrm{HHI}$ ). The concentration ratio shows the market share of the biggest TV channels. In this article concentration ratio has been calculated and analyzed for the three to five biggest channels. Although concentration ratio is easy to calculate and to understand, its main disadvantage is that it does not include all channels on the market. Because of this, concentration ratio is often combined together with HHI of concentration. HHI of concentration is the measure which is calculated using the data of market shares of all TV channels on the market. All regression trend models in this paper have been developed for both concentration ratios and HHI of concentration.

After the Croatian television market had become privatized, new competitors entered the market. All newcomers took a portion of the market from the already existing TV stations. This was Croatian radio television (HRT) initially as it was the market monopolist at that time. The entrance of new competitors lowers the rate of market concentration. As there are more newcomers on the market, the level of market concentration was being lowered every year. Although new competitors have lowered the market concentration of Croatian television market, there still are several TV stations with significant market share.

\section{Analysis of the market}

Currently there are 11 TV channels on the national TV market in Croatia. There is insufficient data for the share of RTL Kockica, hence the analysis will be done using the data for 10 TV channels. The market share is represented by the SHR method that shows the percentage of all people watching television who are tuned to a specific program or station at a specified time. If there are 100 people watching TV, and 20 of them watch a specific channel, then this channel has SHR value $20 \%$.

Table 2 shows the average annual values of share for the total population for the whole day. The analysis starts from 2004 when there were four national TV channels. At that time HRT 1 was the market leader with $39.09 \%$ of the market. The second most-viewed national channel was RTL with 25.76\%. The third channel was HRT 2 with $17.79 \%$, and the fourth Nova TV with $14.26 \%$. Eleven years after this, Croatian national TV market had 11 channels. The most viewed channel in 2014 is Nova TV with $22.99 \%$, on the second place is HRT 1 with $15.96 \%$, and third is RTL with $13.99 \%$.

Especially interesting is to observe the last row in Table 2. It shows the total share of all national TV channels on the market. (The rest of the market are local TV channels, satellite TV channels and cable TV channels). From 2004 to 2014 the share of national TV channels on the total TV market was falling from $96.90 \%$ to $79.38 \%$. This indicates that local, satellite and cable TV channels are gaining in popularity. 
Table 2. The market share of Croatian TV stations (\% of all TV channels).

\begin{tabular}{|c|c|c|c|c|c|c|c|c|c|c|c|}
\hline \multirow[b]{2}{*}{ Channel name } & \multicolumn{11}{|c|}{ Year } \\
\hline & 2004 & 2005 & 2006 & 2007 & 2008 & 2009 & 2010 & 2011 & 2012 & 2013 & 2014 \\
\hline HTV1 & $39.09 \%$ & $38.18 \%$ & $34.61 \%$ & $33.16 \%$ & $32.62 \%$ & $31.50 \%$ & $26.86 \%$ & $21.19 \%$ & $19.60 \%$ & $16.78 \%$ & $15.96 \%$ \\
\hline HTV2 & $17.79 \%$ & $15.79 \%$ & $17.74 \%$ & $16.07 \%$ & $14.00 \%$ & $12.31 \%$ & $11.30 \%$ & $8.89 \%$ & $9.35 \%$ & $7.90 \%$ & $8.32 \%$ \\
\hline HTV3 & & & & & & & & & $1.12 \%$ & $1.43 \%$ & $1.67 \%$ \\
\hline HTV4 & & & & & & & & & & & $2.48 \%$ \\
\hline NovaTV & $14.26 \%$ & $13.48 \%$ & $15.08 \%$ & $17.56 \%$ & $19.48 \%$ & $20.58 \%$ & $23.17 \%$ & $23.64 \%$ & $24.59 \%$ & $24.95 \%$ & $22.99 \%$ \\
\hline RTL & $25.76 \%$ & $24.77 \%$ & $24.61 \%$ & $23.79 \%$ & $22.88 \%$ & $22.15 \%$ & $21.35 \%$ & $17.44 \%$ & $16.74 \%$ & $15.80 \%$ & $13.99 \%$ \\
\hline Doma TV & & & & & & & & $4.07 \%$ & $4.87 \%$ & $4.98 \%$ & $5.30 \%$ \\
\hline RTL 2 & & & & & & & & $4.12 \%$ & $3.92 \%$ & $4.01 \%$ & $4.04 \%$ \\
\hline Sportska Televizija & & & & & & & & $0.44 \%$ & $0.41 \%$ & $0.45 \%$ & $0.29 \%$ \\
\hline Croatian Music Channel & & & & & & & & $1.96 \%$ & $1.68 \%$ & $1.69 \%$ & $1.56 \%$ \\
\hline RTL Kockica & & & & & & & & & & & $2.78 \%$ \\
\hline Share of national channels & $96.90 \%$ & $92.22 \%$ & $92.04 \%$ & $90.58 \%$ & $88.98 \%$ & $86.54 \%$ & $82.68 \%$ & $81.75 \%$ & $82.28 \%$ & $77.99 \%$ & $79.38 \%$ \\
\hline
\end{tabular}

Source: Electronic Media Agency (2012).

Table 3. The market share of Croatian TV stations (\% of nationwide TV channels).

\begin{tabular}{|c|c|c|c|c|c|c|c|c|c|c|c|}
\hline \multirow[b]{2}{*}{ Channel name } & \multicolumn{11}{|c|}{ Year } \\
\hline & 2004 & 2005 & 2006 & 2007 & 2008 & 2009 & 2010 & 2011 & 2012 & 2013 & 2014 \\
\hline HTV1 & $40.34 \%$ & $41.40 \%$ & $37.60 \%$ & $36.61 \%$ & $36.66 \%$ & $36.40 \%$ & $32.49 \%$ & $25.92 \%$ & $23.82 \%$ & $21.52 \%$ & $20.11 \%$ \\
\hline HTV2 & $18.36 \%$ & $17.12 \%$ & $19.27 \%$ & $17.74 \%$ & $15.73 \%$ & $14.22 \%$ & $13.67 \%$ & $10.87 \%$ & $11.36 \%$ & $10.13 \%$ & $10.48 \%$ \\
\hline HTV3 & & & & & & & & & $1.36 \%$ & $1.83 \%$ & $2.10 \%$ \\
\hline HTV4 & & & & & & & & & & & $3.12 \%$ \\
\hline NovaTV & $14.72 \%$ & $14.62 \%$ & $16.38 \%$ & $19.39 \%$ & $21.89 \%$ & $23.78 \%$ & $28.02 \%$ & $28.92 \%$ & $29.89 \%$ & $31.99 \%$ & $28.96 \%$ \\
\hline RTL & $26.58 \%$ & $26.86 \%$ & $26.74 \%$ & $26.26 \%$ & $25.71 \%$ & $25.60 \%$ & $25.82 \%$ & $21.33 \%$ & $20.35 \%$ & $20.26 \%$ & $17.62 \%$ \\
\hline Doma TV & & & & & & & & $4.98 \%$ & $5.92 \%$ & $6.39 \%$ & $6.68 \%$ \\
\hline RTL 2 & & & & & & & & $5.04 \%$ & $4.76 \%$ & $5.14 \%$ & $5.09 \%$ \\
\hline Sportska Televizija & & & & & & & & $0.54 \%$ & $0.50 \%$ & $0.58 \%$ & $0.37 \%$ \\
\hline Croatian Music Channel & & & & & & & & $2.40 \%$ & $2.04 \%$ & $2.17 \%$ & $1.97 \%$ \\
\hline RTL Kockica & & & & & & & & & & & $3.50 \%$ \\
\hline
\end{tabular}

As there is a certain proportion which goes on other TV channels (satellite, cable, and local), values from Table 2 will first be transformed in the way that they give the sum of $100 \%$ and then analysis will be done with such data (Table 3). The reason for this is focusing the analysis on the channels with nationwide coverage.

The analysis of the market will be done from the aspect of market concentration. Five measures of concentration will be calculated and discussed. The first four of them are concentration ratios $(\mathrm{C} 1$, $\mathrm{C} 2, \mathrm{C} 3, \mathrm{C} 4)$, and the fifth is the HHI of concentration (HHI).

Concentration ratio is calculated as

$$
C_{r}=\frac{\sum_{i=1}^{r} x_{i}}{\sum_{i=1}^{n} x_{i}}
$$

where $n$ denotes the total number of market participants, $r$ the number of largest participants for which concentration is being calculated and $x_{i}$ the individual value of market share. The value of $\mathrm{Cr}$ can vary from $0 \%$ to $100 \%$, where higher value shows higher concentration level. Concentration ratios show the market share of largest TV channels. C1 shows the market share of the largest TV channel, C2 market share of two largest TV channels, C3 is the market share of three leading TV channels, and C4 market share of first four TV channels. 
HHI of concentration is calculated as

$$
H H I=\sum_{i=1}^{n} p_{i}^{2}
$$

where $p_{i}$ denotes the share of each individual market participant and $n$ the total number of market participants. The value of HHI can vary from $1 / 10,000$ to 10,000 . Lower values of HHI indicate higher level of market competition and vice versa (Griffiths \& Wall, 1996). The values of HHI lower than 1000 show low concentration, the values between 1000 and 1,800 characterize moderate concentration, and the value of HHI greater than 1,800 indicates high concentration (Hüschelrath, 2008; Stone, 2010; Tipurić, Pejić Bach, \& Pavić, 2008).

The values of concentration ratios for the three and five channels with biggest market share, as well as HHI of concentration, are shown in Table 4. To demonstrate the trends of concentration ratios, the values of $\mathrm{C} 3$ and $\mathrm{C} 5$ are shown graphically. Concentration ratios $\mathrm{C} 3$ and $\mathrm{C} 5$ have the negative trend, which means they are diminishing each year. This means that the leading TV channels are losing their share. Here it is interesting to mention that from 2004 to 2010 the leading TV channel was HRT 1, and from 2011 to 2014 the first position was taken by Nova TV, a foreign company. In 2014 the three leading channels have $66.69 \%$ of the market, and five leading channels have $83.85 \%$ of the market.

HHI of concentration is shown in the first column of the Table 4. The value of HHI has diminished in the analyzed period from $2,887.7$ to $1,764.4$. As the value of 1,800 is the border between high and moderate concentration level, it is obvious that the value of HHI on Croatian TV market for nationwide channels just crossed the line and from 2014 became a moderately concentrated market.

Our results indicate that the Croatian TV market for channels with nationwide coverage is still relatively highly concentrated. The level of concentration has been falling from 2004 to 2014, and if the same trend continues, the market should become moderately concentrated in next few years. This should happen primarily by losing the share of the four biggest TV channels (Nova TV, HRT 1, RTL, HRT 2) in favor of other TV channels with nationwide coverage.

\section{Forecasting trends}

Based on the data for the period from 2004 to 2014, we calculated the predicted values for market share for each channel that is broadcasting on a nationwide level in Croatia. To predict the values for estimating this trend, first we explored if the changes in market share are approximately linear or not. This can be seen from their graphical comparison.

From Figure 2 it is obvious that some trends are close to linear, but some of them are not. Competing stations in the Croatian TV market cannot be regarded as perfect substitutes. They are close substitutes, and despite the fact that TV stations operate on the same national market, some of

Table 4. Values of Herfindahl-Hirschman Index (HHI) and concentration ratios (2004-2014).

\begin{tabular}{lcrr}
\hline Year & HHI & C3 & C5 \\
\hline 2004 & 2887.7 & $85.28 \%$ & $100.00 \%$ \\
2005 & 2942.3 & $85.38 \%$ & $100.00 \%$ \\
2006 & 2768.9 & $83.62 \%$ & $100.00 \%$ \\
2007 & 2720.6 & $82.26 \%$ & $100.00 \%$ \\
2008 & 2732.0 & $84.27 \%$ & $100.00 \%$ \\
2009 & 2747.9 & $85.78 \%$ & $100.00 \%$ \\
2010 & 2694.3 & $86.33 \%$ & $100.00 \%$ \\
2011 & 2137.7 & $76.17 \%$ & $92.09 \%$ \\
2012 & 2067.7 & $74.05 \%$ & $91.33 \%$ \\
2013 & 2075.0 & $73.77 \%$ & $90.28 \%$ \\
2014 & 1764.4 & $66.69 \%$ & $83.85 \%$ \\
\hline
\end{tabular}


them target a special group of people, usually from 18 to 49 years old. On other hand, there is currently no station which is specialized for a niche market, and all stations are intended for the broad public.

As already explained before, we have tested four basic econometric models for each TV channel. All of these regression models are based on the method of least squares. This method suggests that the difference between the real and expected values of the dependent variable is the smallest possible (Maddala, 2006; Maddala \& Lahiri, 2009; McClave \& Sincich, 2012), that means

$$
\sum_{i=1}^{n}\left(y_{i}-\hat{y}_{i}\right) \rightarrow \min
$$

The method of least squares is based on the following assumption:

(1) the expected value of error is zero;

(2) the variance of error is constant;

(3) all errors are independent.

Because of these three assumptions, the method of least squares is today widely used in econometric analyses, primarily in cases of linear or close to linear relationship between variables. The method of least squares is often characterized as BLUE (best linear unbiased estimator), because its estimators have desirable optimal properties.

After the analysis of all four models for each TV station, we have concluded that following models shown in Table 5 best fit our data. From all models that we have tested, our best results were from three linear trends, two 2 exponential trends, two logarithmic trends, and two power trends. In most cases the R-squared is high, but for 2 TV stations it is much lower. The reason for this is the smaller number of observations, but also the trend is not the same during the years. These 2 TV stations have different trends regarding rise and fall of market share during the analyzed period. As their share is not large, this is not a limitation for further analysis of market concentration.

Based on our models, we calculated the predicted values for market share of each of Croatian national TV channels (Table 6). As for HRT 4 and RTL Kockica, there is data available for only 1 year and as such there was no possibility to make the trend. Because of this, we made the assumption that their market share will remain constant over next 3 years. Under the assumption that all of estimated trends remain the same after the period 2004-2014, as they have been during this period, the calculated estimated values for market share trends are shown in the following table.

The data from the table show that the share of national TV channels on the total TV market is expected to fall in next three years. To analyze the market shares only for national TV stations, we have recalculated values of market share of all TV stations, as explained before. This is shown in Table 7.

From the table it is illustrated that the market leader will remain Nova TV with an expected rise in market share. Starting from 2015, RTL is expected to replace HRT 1 in second position. From the

Table 5. Chosen regression models for estimating future values.

\begin{tabular}{lcc}
\hline Channel name & Selected model & Coefficient of correlation \\
\hline HRT 1 & $\mathrm{y}=0.4319-0.0251 \mathrm{t}$ & $\mathrm{R}^{2}=0.9625$ \\
HRT 2 & $\mathrm{y}=0.2084 \mathrm{e}^{-0.09 t}$ & $\mathrm{R}^{2}=0.9301$ \\
HRT 3 & $\mathrm{y}=0.0112 \mathrm{t}^{0.3624}$ & $\mathrm{R}^{2}=0.9995$ \\
HRT 4 & No sufficient data & $\mathrm{R}^{2}=0.8858$ \\
Nova TV & $\mathrm{y}=0.1268+0.0122 \mathrm{t}$ & $\mathrm{R}^{2}=0.9432$ \\
RTL & $\mathrm{y}=0.2807-0.0121 \mathrm{t}$ & $\mathrm{R}^{2}=0.9592$ \\
Doma TV & $\mathrm{y}=0.0413+0.0085 \ln (\mathrm{t})$ & $\mathrm{R}^{2}=0.1650$ \\
RTL 2 & $\mathrm{y}=0.0407+0.0006 \ln (\mathrm{t})$ & $\mathrm{R}^{2}=0.5350$ \\
SPTV & $\mathrm{y}=0.0052 \mathrm{e}^{-0.116 \mathrm{t}}$ & $\mathrm{R}^{2}=0.9098$ \\
CMC & $\mathrm{y}=0.0194 \mathrm{t}^{-0.152}$ & \\
RTL Kockica & No sufficient data & \\
\hline
\end{tabular}


Table 6. Predicted values of the market share based on calculated regression coefficients for the period 2015-2017 (as \% of total TV market).

\begin{tabular}{lrrr}
\hline & \multicolumn{1}{c}{ Year } \\
\cline { 2 - 4 } Channel name & \multicolumn{1}{c}{2015} & 2016 & 2017 \\
\hline HRT1 & $13.09 \%$ & $10.58 \%$ & $8.07 \%$ \\
HRT2 & $7.08 \%$ & $6.47 \%$ & $5.91 \%$ \\
HRT3 & $1.85 \%$ & $2.01 \%$ & $2.14 \%$ \\
HRT4 & $2.48 \%$ & $2.48 \%$ & $2.48 \%$ \\
Nova TV & $27.28 \%$ & $28.50 \%$ & $29.72 \%$ \\
RTL & $13.61 \%$ & $12.41 \%$ & $11.20 \%$ \\
Doma TV & $5.50 \%$ & $5.65 \%$ & $5.78 \%$ \\
RTL 2 & $4.17 \%$ & $4.18 \%$ & $4.19 \%$ \\
Sportska Televizija & $0.29 \%$ & $0.26 \%$ & $0.23 \%$ \\
Croatian Music Channel & $1.52 \%$ & $1.48 \%$ & $1.44 \%$ \\
RTL Kockica & $2.78 \%$ & $2.78 \%$ & $2.78 \%$ \\
Share of national TV channels & $79.65 \%$ & $76.79 \%$ & $73.95 \%$ \\
\hline
\end{tabular}

four most important TV stations which are being broadcasted in multiplex A (HRT 1, HRT 2, RTL, Nova TV), only Nova TV is expected to see a rise in market share, while the other three should lose market share. All other TV stations (except Sportska Televizija) will experience growth of market share.

Now based on these results, we can analyze the trends in market concentration for the period from 2015 to 2017. The concentration ratio C3 should rise in 2015 and then fall in next 2 years. Concentration ratio $\mathrm{C} 5$ is expected to continue diminishing its value through next 3 years. The value of HHI is, contrary to concentration ratios, expected to rise. This can be explained with the fall of market share of the second, third and fourth TV station, which is more than compensated by the rise in market share of market leader. Generally speaking, Croatian public TV channels will continue losing their audience, while the majority of other private TV channels will gain new audience.

\section{Microeconomic analysis of the market (market structures)}

Market structure is the situation of the market with respect to competition. In the contemporary microeconomics there are four main market structures (Besanko \& Braeutigam, 2010; Browning \& Zupan, 2011; Hall \& Lieberman, 2012; Goolsbee, Levitt, \& Syverson, 2013):

(1) Monopoly

(2) Oligopoly

(3) Monopolistic competition

(4) Perfect competition

These market structures differ because of the difference of basic characteristics, such as number of sellers and buyers, product type, barriers to entry, and so on. The two extremes are monopoly and perfect competition, whereas oligopoly and monopolistic competition have characteristics of both monopoly and perfect competition.

Monopoly is the market structure in which there is only one producer which produces a product or service that has no close substitutes. This means that a product is unique and that the only possibility for costumers to have the product is to buy it from the monopolist. The monopolistic market is closed for any other company that would like to enter the market. This can be due to different reasons: regulatory, technical or natural.

Perfect competition is the market structure totally different from monopoly. It is characterized by the large number of producers, who all produce the homogenous product. Homogenous product means that all products from different producers look the same from the perspective of buyers in all the main attributes. The entry in the market is totally free, as well as the possibility to exit the 
Table 7. Literature overview.

\begin{tabular}{|c|c|c|c|}
\hline Author(s) & Industry/field & Journal name & Key issues and main findings \\
\hline Chen (2002) & Television & $\begin{array}{l}\text { The Journal of Media } \\
\text { Economics }\end{array}$ & $\begin{array}{l}\text { Taiwan's cable systems and channels are highly concentrated } \\
\text { (CR4 = 74.3\%) in the hands of a few media conglomerates, } \\
\text { meaning that the cable industry has become more oligopolistic; } \\
\text { mergers and acquisitions among Taiwan's cable systems have } \\
\text { dramatically changed the operation and ownership of the cable } \\
\text { industry }\end{array}$ \\
\hline $\begin{array}{l}\text { Van Der Wurff } \\
\text { (2005) }\end{array}$ & Television & $\begin{array}{l}\text { Journal of Cultural } \\
\text { Economics }\end{array}$ & $\begin{array}{l}\text { Focuses on free, national generalist channels and tests } \\
\text { hypotheses with data on Finland, France, Germany, Greece, } \\
\text { Italy, the Netherlands, Spain and the United Kiingdom for the } \\
\text { late } 1980 \text { s and 1990s; the conclusion is that competition is } \\
\text { moderate in most markets; one important and consistent } \\
\text { finding is that increases in channel numbers result in lower } \\
\text { levels of channel reflective diversity and higher levels of channel } \\
\text { distinctiveness }\end{array}$ \\
\hline Johannes (2010) & Television & $\begin{array}{l}\text { The Business Review } \\
\text { Cambridge }\end{array}$ & $\begin{array}{l}\text { Market concentration of the cable television industry in the } \\
\text { United States from } 1996 \text { to } 2008 \text { has increased significantly } \\
\text { measured by CR4, CR8, and HHI; the industry was a moderately } \\
\text { concentrated oligopoly, but merger and acquisition activity } \\
\text { started to increase the concentration and the market became } \\
\text { highly concentrated oligopoly }\end{array}$ \\
\hline $\begin{array}{l}\text { Gutiérrez Rentería } \\
\text { (2007) }\end{array}$ & Television & $\begin{array}{l}\text { International Journal } \\
\text { on Media } \\
\text { Management }\end{array}$ & $\begin{array}{l}\text { Analyzes multimedia industry concentration in Mexico; this } \\
\text { paper explores the principal strategies used by TV Azteca to } \\
\text { overcome the entry barriers set by the Televisa monopoly and } \\
\text { presents an economic valuation of this duopoly market } \\
\text { structure; the study assumes the hypothesis that for a new } \\
\text { participant to overcome entry barriers established by a } \\
\text { monopoly, its directors must develop both vertical and } \\
\text { horizontal strategies, as well as strategies focused on content } \\
\text { innovation }\end{array}$ \\
\hline $\begin{array}{l}\text { Vázquez-Maguirrea } \\
\text { and Hartmann } \\
\text { (2013) }\end{array}$ & Television & $\begin{array}{l}\text { Journal of Business } \\
\text { Research }\end{array}$ & $\begin{array}{l}\text { Analyzes the nonmarket strategies of the Mexican television } \\
\text { duopoly in order to reach an understanding of how firms gain } \\
\text { and maintain first-mover advantages by influencing } \\
\text { policymakers; clear evidence shows that the incumbent duopoly } \\
\text { has used its nonmarket strategies to accrue wealth and prevent } \\
\text { new competitors from entering the Mexican television industry }\end{array}$ \\
\hline $\begin{array}{l}\text { Löbbecke and } \\
\text { Falkenberg } \\
(2002)\end{array}$ & Television & $\begin{array}{l}\text { International Journal } \\
\text { on Media } \\
\text { Management }\end{array}$ & $\begin{array}{l}\text { Investigates the influence of the advent of the Internet on TV } \\
\text { distribution channels; entry barriers to TV markets are being } \\
\text { lowered via the Internet in various forms; potential above } \\
\text { average profits due to the market's oligopolistic structure, as } \\
\text { well as an increased contestability thanks to lower market entry } \\
\text { barriers, seem to render the German TV market attractive for } \\
\text { new entrants; the analysis suggests that once technical and } \\
\text { legal constraints have been overcome, the Internet could be an } \\
\text { attractive additional distribution channel for some types of } \\
\text { television content }\end{array}$ \\
\hline $\begin{array}{l}\text { Rennhoff and } \\
\text { Wilbur (2012) }\end{array}$ & Television & $\begin{array}{l}\text { Information Economics } \\
\text { and Policy }\end{array}$ & $\begin{array}{l}\text { The study investigates how local media cross-ownership, co- } \\
\text { ownership and ownership diversity are associated with media } \\
\text { market outcomes; results have shown that television station } \\
\text { ownership consolidation is associated with increased local TV } \\
\text { news production but lower news ratings; panel estimation finds } \\
\text { that changes in local media ownership are uncorrelated with } \\
\text { local media usage or programming, producing confidence } \\
\text { intervals that are tightly centered around zero }\end{array}$ \\
\hline Berg (2010) & Television & $\begin{array}{l}\text { Public Service Media } \\
\text { after the Recession }\end{array}$ & $\begin{array}{l}\text { Investigates the market concentration for television markets in } \\
\text { the } 33 \text { sample markets; results show that these markets } \\
\text { continue to be under conditions of oligopoly ranging from } \\
\text { moderately to highly concentrated; the relationship between } \\
\text { size and market concentration is questioned using a market } \\
\text { intervention approach; the results show that market } \\
\text { intervention alters the rules of the game, and that based on this } \\
\text { analysis the impact of size on market concentration might be a } \\
\text { myth }\end{array}$ \\
\hline
\end{tabular}


Table 7. (Continued).

\begin{tabular}{|c|c|c|c|}
\hline Author(s) & Industry/field & Journal name & Key issues and main findings \\
\hline $\begin{array}{l}\text { Rotundo and } \\
\text { D'Arcangelis } \\
\text { (2014) }\end{array}$ & Television & Quality \& Quantity & $\begin{array}{l}\text { Propose an adjustment to the Herfindahl-Hirschman } \\
\text { concentration index for explicitly considering the role of the } \\
\text { topology of financial economic networks on market } \\
\text { concentration; authors deepen the analysis of the network } \\
\text { comparing network centrality measures that are a well-known } \\
\text { method for understanding the relative relevance of network } \\
\text { nodes }\end{array}$ \\
\hline $\begin{array}{l}\text { Schmid and Ulrich } \\
\text { (2013) }\end{array}$ & $\begin{array}{l}\text { Medical care, } \\
\text { hospital }\end{array}$ & Health Policy & $\begin{array}{l}\text { Analyze the German hospital market; findings indicate that just } \\
\text { some years after hospital competition was intensified, more } \\
\text { than one third of German hospitals are located in strongly } \\
\text { concentrated markets; this approach is very interesting, but } \\
\text { unfortunately it could be applied only for local TV stations, and } \\
\text { not for national TV stations }\end{array}$ \\
\hline $\begin{array}{l}\text { Chong-En, Jie, } \\
\text { Qiong (2014) }\end{array}$ & $\begin{array}{c}\text { Chinese } \\
\text { industry } \\
\text { concentration }\end{array}$ & $\begin{array}{l}\text { China Economic } \\
\text { Review }\end{array}$ & $\begin{array}{l}\text { Use the nonlinear estimation method to simulate the Zipf } \\
\text { distribution, and construct an alternative measure of } \\
\text { Hirschman-Herfindahl index (HHI), in order to reveal the real } \\
\text { changes in monopoly of China's industrial markets; based on } \\
\text { the annual waves of the Chinese Industrial Enterprises Database } \\
\text { between } 1998 \text { and } 2009 \text {, it finds that systematic bias of } \\
\text { deceptive declining concentration would be very easy to appear } \\
\text { when directly using censored survey data with some invariant } \\
\text { threshold }\end{array}$ \\
\hline George (2007) & Newspaper & $\begin{array}{l}\text { Information Economics } \\
\text { and Policy }\end{array}$ & $\begin{array}{l}\text { Examines the effect of ownership concentration on product } \\
\text { position, product variety and circulation in the US daily } \\
\text { newspaper market; using data at } 706 \text { newspapers in 1993, } 1999 \\
\text { and 2004, results have shown that both differentiation and } \\
\text { variety increase with ownership concentration }\end{array}$ \\
\hline Doyle (2010) & $\begin{array}{l}\text { Television and } \\
\text { culture }\end{array}$ & $\begin{array}{l}\text { Journal of Cultural } \\
\text { Economics }\end{array}$ & $\begin{array}{l}\text { Drawing on an analysis of recent research findings related to } \\
\text { multi-platform strategies in the television industry, the author } \\
\text { examines what is distinctive about economics of culture, and it } \\
\text { assesses the appeals but also the challenges associated with } \\
\text { conducting scholarly research work in this particular area }\end{array}$ \\
\hline $\begin{array}{l}\text { O'Hagan and } \\
\text { Jennings (2003) }\end{array}$ & $\begin{array}{l}\text { Public sector } \\
\text { broadcasting }\end{array}$ & $\begin{array}{l}\text { Journal of Cultural } \\
\text { Economics }\end{array}$ & $\begin{array}{l}\text { Paper deals with some key issues arising in the current debate } \\
\text { in Europe over public sector broadcasting (PSB); it asks what is } \\
\text { understood by PSB and examines critically the arguments for } \\
\text { PSB; paper provides some statistical analysis of the extent, } \\
\text { funding and program mix of European PSB; it examines in some } \\
\text { detail the issues surrounding the license fee as an instrument } \\
\text { for funding PSB }\end{array}$ \\
\hline
\end{tabular}

market. All producers and buyers have the perfect knowledge about all important information, so there is no problem of asymmetric information.

Oligopoly is the market structure which is close to monopoly, but the main difference is in the number of producers. Although in monopoly there is only one producer, in oligopoly there are several producers. They all produce either homogenous product (pure oligopoly) or differentiated product (differentiated oligopoly). All producers are interdependent; every action on the market causes the reaction of all other oligopolists. The process of entering the market is limited, but not impossible.

Monopolistic competition is the market structure which is close to perfect competition, with the main difference in the product type. Although in perfect competition all products are homogenous, in monopolistic competition products are differentiated. Differentiated product means that products from different producers are similar, but not the same. The difference between them is important enough that buyers can notice it and decide on buying the product or not, based on this difference.

In the television market from all these four market structures, only three are possible: monopoly, oligopoly and monopolistic competition. Perfect competition is not possible because TV channels 
are different enough for the audience to notice the difference between them. There are no two identical TV channels in the world. Television programing is not a homogenous product.

The process of development of all national TV markets could be divided into three phases, from which every phase corresponds to a certain market structure. These three phases would be monopoly (Phase 1), oligopoly (Phase 2), and monopolistic competition (Phase 3).

Phase 1 occurs at the beginning of the development of TV market. This is usually in the middle of $20^{\text {th }}$ century, when national broadcasting corporations started to broadcast TV program. All these channels were state-owned and for a certain period these channels had been the only producer of TV programmes in a country. Phase 2 begins with the entry of second TV channel on the market. The entry of other TV channels still remains in Phase 2. When the number of TV channels on a certain market is high enough to lower the market concentration, Phase 3 begins. This is the current situation on national TV markets of the most developed countries in the television sense (e.g., Germany, France, or Italy).

Croatia had spent a long time in Phase 1, ending just in the year 2000. Today's situation on Croatian TV market can be described as oligopolistic, which means that Croatia is still in Phase 2. The number of TV channels on nationwide level is not so small, but the market concentration is still high. In microeconomic theory there is no specific border between oligopoly and monopolistic competition regarding the number of producers, but even if this number is high and the level of market concentration is also high, such structure would be oligopoly rather than monopolistic competition. Based on all of this, the Croatian TV market for stations on a national level is oligopoly, and taking into account the predicted values of market share and market concentration for next three years, it will remain in the same structure.

\section{Conclusion and implications}

The Croatian television case example can help other countries to predict developments in their own TV market. Croatia is the EU country closest to the Western Balkan countries, who all aspire to obtain membership in the EU. Thus, the Croatian data may have valuable implications for Western Balkans and other Central and Eastern European countries. Our research results focusing on Croatia can be applied to other national markets when customized for the local culture. Specifically, before new TV channel releases, foreign TV stations tend to generate generally higher expectations.

The public television HRT was once the monopolist, but with the liberalization of the market, other private TV channels entered the market taking significant market shares. From the very beginning when the Croatian TV market became liberalized, the market concentration began to change. The analysis showed the data and the trend from 2006 to 2012, in which the level of market concentration measured by $\mathrm{HHI}$, has been falling from 2,768 to 2,123. Concentration level also showed a diminishing trend, which is the consequence of the rise of popularity of TV channels with lower market share, as well as of the entry of new TV channels in the market.

Generally speaking, Croatian public TV channels will continue losing their audience, while the majority of other private TV channels will gain new audiences. Viewership is now based upon the needs and demands of the marketplace, and the free market is unrestrained by the government. Of greater impact is the globalization of the industry, as the leading firm in the Croatian market currently is a foreign firm broadcasting in Croatia. These firms offer a global perspective and are not influenced by the government and offer programming that will deliver an eclectic view. Transitional governments that are seeking transparency in reporting, and programs chosen only for their success measured by the number of viewers, should take note of the privatization outcomes illustrated in our research.

The trend models developed in this article show that the market concentration in the next couple of years could experience a slow rise. The reason for this is the expected rise of market shares of the leading TV channels. Regarding market structure, the conclusion is that the current market structure 
of the Croatian TV market is an oligopoly, which in a mature market will likely to continue. This is very important information for any possible new TV channel that could enter Croatian TV market and that would be treated as foreign direct investment (FDI) by the EU. This also has strong positive implications for "first movers" into a newly deregulated market place.

Our research gives further guidance for practitioners in the industry in regard to industry characteristics. Besides TV channels at a national level, there are also TV channels at a local level as well as satellite and cable TV channels. Although the large national providers will continue to concentrate their viewership, substitute products such as cable, internet, dish, etc. will continue to gain market share at their expense. However, because their power in the industry and number of programs, they could well integrate into these platforms and stifle competition from these substitutes.

Our research furthers the relatively little previous research that examines the television market in the EU. The research is important as a case study, because not only does it illustrate past trends in the EU, but is informative for other countries that are deregulating their television marketplaces (such as in the Central and Eastern Europe). Our research illustrates that a deregulated TV market will follow a pattern of monopolistic market to oligopolistic over time, with the former monopoly suffering the greatest loss of market share. Our results indicate further changes in market concentration as specialized TV channels continue to enter the market, and again, with the former monopolistic government TV channel losing the most market share.

One key limitation of our research is that the industry itself is evolving with the advent of cable, internet and satellite providers entering the industry, from outside the marketplace of Croatia. In all television markets globally, this phenomenon is causing concern to practitioners in the industry. We also cannot predict if, or how many, new television stations will occur in Croatia within the next years, and what (if any) impact they will have on the market.

The further limitation of this study is that there are no similar studies for countries with similar population and culture as Croatia. On other hand this can also be regarded as an advantage because this is the first article that can incite other future research. In future research we plan to repeat the same analysis in next 5 years and do a longitudinal analysis. One of the limitations of our study is the lack of the analysis of standard errors of the parameters calculated in the model.

\section{Notes on contributors}

Fran Galetić and Marina Dabić are both with the Faculty of Economics and Business, University of Zagreb, Zagreb, Croatia.

Timothy Kiessling is with the Faculty of Business Administration, Bilkent University, Ankara, Turkey.

\section{ORCID}

Marina Dabić (iD http://orcid.org/0000-0001-8374-9719

\section{References}

Bagdikian, B. H. (2004). The new media monopoly. Boston, MA: Beacon Press.

Baker, E. C. (2007). Media concentration and democracy: Why ownership matters. Cambridge, UK: Cambridge University Press.

Barnett, S. (2010). What's wrong with media monopolies? A lesson from history and a new approach to media ownership policy. Media@LSE Electronic Working Papers, No. 18.

Berg, C. E. (2010). Market concentration and transnational ownership-a comparative analysis: Public Service Media after the Recession. Westminster, UK: RIPEat.org.

Besanko, D., \& Braeutigam, R. R. (2010). Microeconomics. Hoboken, NJ: John Wiley and Sons.

Browning, E. K., \& Zupan, M. A. (2011). Microeconomics: Theory and applications. Hoboken, NJ: John Wiley and Sons. 
Chen, P. H. (2002). Who owns cable television? Media ownership concentration in Taiwan, The Journal of Media Economics, 15, 41-55.

Chong-En, B., Jie, M., \& Qiong, Z. (2014). Measuring market concentration in China: The problem with using censored data and its rectification. China Economic Review, 30, 432-447.

Dahlgren, P. (2000). Key trends in European television. In J. Wieten, G. Murdock, \& P. Dahlgren (Eds.), Television across Europe (pp. 23-34). London, UK: Sage.

Doyle, G. (2010). Why culture attracts and resists economic analysis. Journal of Cultural Economics, 34, $245-259$.

Electronic Media Agency. (2012). Analysis of TV market. Retrieved from http://www.e-mediji.hr/repository_files/file/26/

George, L. (2007). What's fit to print: The effect of ownership concentration on product variety in daily newspaper markets, Information Economics and Policy, 19, 285-303.

Goolsbee, A., Levitt, S., \& Syverson, C. (2013). Microeconomics. New York, NY: Macmillan Higher Education.

Griffiths, A., \& Wall, S. (1996). Intermediate microeconomics, theory and applications. London, UK: Longman.

Gutiérrez Rentería, M. E. (2007). Media concentration in the Hispanic market: A case study of TV Azteca vs. Televisa. International Journal on Media Management, 9, 70-76.

Hall, R. E., \& Lieberman, M. (2012). Microeconomics: Principals and applications. Boston, MA: Cengage Learning.

Hüschelrath, K. (2008). Competition policy analysis: An integrated approach. Heidelberg, Germany: Physica-Verlag.

Iosifides, P. (1999). Diversity versus concentration in the deregulated mass media domain. Journalism e Mass Communication Quarterly, 76, 152-162.

Johannes, S. (2010). Concentration in the cable television industry from 1996-2008. The Business Review, 16.

Löbbecke, C., \& Falkenberg, M. (2002). A framework for assessing market entry opportunities for internet-based TV. International Journal on Media Management, 4, 95-104.

Maddala, G. S. (2006). Introduction to econometrics. Hoboken, NJ: Wiley.

Maddala, G. S., \& Lahiri, K. (2009). Introduction to econometrics. New York, NY: Wiley.

McClave, J. T., \& Sincich, T. (2012). Statistics (12th ed.). New York, NY: Pearson.

O’Hagan, J., \& Michael, J. (2003). Public broadcasting in Europe: Rationale, licence fee and other issues. Journal of Cultural Economics, 27, 31-56.

OIV Ltd. (n.d.). DVB-T: Television of the New Era. Retrieved from http://www.oiv.hr/broadcasting/terrestrial/dtv/dtv_ hr.aspx

Rennhoff, A. D., \& Wilbur, K. C. (2012). Local media ownership and media quality. Information Economics and Policy, 24, 231-242.

Rotundo, G., \& D’Arcangelis, A. M. (2014). Network of companies: an analysis of market concentration in the Italian stock market. Quality \& Quantity, 48, 1893-1910.

Schmid, A., \& Ulrich, V. (2013). Consolidation and concentration in the German hospital market: The two sides of the coin. Health Policy, 109, 301-310.

Stone, G. (2010). Core economics. London, UK: Worth.

Tipurić, D., Pejić Bach, M., \& Pavić, T. (2008). Concentration of the insurance industry in selected transition countries of Central and Eastern Europe, 1998-2006. Post-Communist Economies, 20, 97-118.

Van Der Wurff, R. (2005). Competition, concentration and diversity in European television markets. Journal of Cultural Economics, 29, 249-275.

Vázquez-Maguirrea, M., \& Hartmann, A. M. (2013). Nonmarket strategies of media enterprises in the Mexican television industry. Journal of Business Research, 66, 1743-1749.

Ward, D. (2004). A mapping study of media concentration and ownership in ten European countries. Hilversum, The Netherlands: Commissariaat voor de Media.

Zampetakis, L. A., Vekini, M., \& Moustakis, V. (2011). Entrepreneurial orientation, access to financial resources, and product performance in the Greek commercial TV industry, The Service Industries Journal, 31, 897-910. 